\title{
Editorial
}

\section{Riding a wave of creative destruction - reflections on Ecology and Society}

\author{
Lance Gunderson $^{1}$, Carl Folke $^{2,3}$, and Michelle Lee $^{4}$
}

Key Words: Ecology and Society; creative destruction,

\section{It is with deepest regret that the Editors and staff of Ecology and Society learned of the death, on May 26, 2010, of Rosanna Bechtel, the senior copy editor for the journal and an invaluable part of the copy editing team for over a decade. Despite suffering from a long term illness, Rosanna edited for Ecology and Society with both dedication and enthusiasm until the last few weeks prior to her death. Rosanna's sharp wit and a mastery of the pen endeared her to journal staff and authors alike. We extend our deepest condolences to Rosanna's family and friends.}

Not too long ago, checkout clerks at food stores inquired, "Paper or plastic?", referring to the type of bags to carry home one's groceries. A similar question is now being asked about much published scholarship, except that the choice is now paper or electrons. By electrons, I mean a digital medium, in which the information is developed, produced, and stored entirely on computers, in stark contrast to the volumes of paper journals that now line the shelves of libraries and many professors' offices. To be fair, most journals that we read are now published in both paper and electronic formats. This shift marks more than a change of format, however. It is a sea change, the kind of transformation that the Austrian economist Joseph Schumpeter said was caused by "gales of creative destruction." In his model, systems change when new ideas, products, and technologies bring about the destruction of the old.
The emergence of digital scholarship appears to follow this model: the freely accessible electronic media is replacing the more expensive, paper based one.

Ecology and Society (www.ecologyandsociety.org ) was one of the first entirely digital journals. Many journals that began in print now produce both paper and electronic versions, but Ecology and Society has always lived exclusively in a virtual world. It was developed following a challenge to a handful of graduate students at Carleton University in the mid 1990s. After four years of hard work gathering funds and writing software, the first issue was published, "posted" might be a better word, in 1997. At the time of this writing, the $15^{\text {th }}$ issue is underway. For the past seven years, we have edited the journal. Over the past decade, the journal has grown into an internationally recognized, highly respected publication.

Ecology and Society focuses on the interactions between people and their environment. Actually, we regard people and the environment as intertwined social-ecological systems. Specifically, we publish articles that deal with "the management, stewardship and sustainable use of ecological systems, resources and biological diversity at all levels, and the role natural systems play in social and political systems and conversely, the effect of social, economic and political institutions on ecological systems and services."

The journal is an open access journal, which means that all of its content is available for free on the internet. We believe that making such work freely and readily available will contribute to a greater global exchange of knowledge and information. The journal has more than 13,000 subscribers in more than 100 countries, with most of the subscribers 
located in North America and Europe. Subscribers pay nothing, but they do register with the journal in order to receive information such as notices when a new issue is published. The journal publishes about 100 articles per year. Funding for the journal comes from a combination of sources, including grants, institutional dues, and page charges.

\section{LESSONS FROM THE JOURNAL}

Focus on quality. Early in the planning stages of the journal, the founders set a goal of development of a high quality product. The threshold for internet publishing is very low; once a few technical obstacles are overcome, such as learning how to develop and create a website, then anyone can publish anything. Ecology and Society set out to become a credible scientific outlet by asking respected scientists to be members of the editorial board, and implementing a double-blind review process for each manuscript. As a result, more than half of the submitted manuscripts are declined. In the past few years, the journal is ranked among the top half a dozen environmental science and environmental studies journals. Indeed, one of our editors, Elinor Ostrom, was awarded the Prize in Economic Sciences in Memory of Alfred Nobel in 2009.

Encourage creativity. The journal fosters publications that explore novel ideas and the application of those ideas by awarding annual prizes. A prize of 500 Euros is awarded to the author (s) of the most original paper that integrates different streams of science to assess fundamental questions in the ecological, political, and social foundations for sustainable social-ecological systems. Another award of 1000 Euros is given annually to the individual or organization that is the most effective in bringing transdisciplinary science into practice. Both of these prizes are donated by a private European foundation.

Stay small and efficient. The journal has become successful because of the hard work of a small group of people. An executive director handles all of the financial and managerial work. A managing editor with great colleagues effectively handles the flow of manuscript submissions, reviews, editing, and final publication. A custom-designed software was developed for the journal in order to manage the entire production process. The editors in chief evaluate each manuscript and oversee the review process that is handled by a network of subject editors and reviewers. The executive director, managing editor, and editors in chief coordinate the large task of manuscript review using the custom software.

Develop an open network of scholars. A pleasant surprise that has emerged from the journal has been the creation of a network of thinkers that has formed around it. That is, the scholars who contribute to the journal, the subscribers who utilize the information, and a small group who facilitate publication all form a network. The first editor suggested that the journal has created a virtual institute, one without walls and a minimal support infrastructure. This network has helped with the funding of major research centers in Sweden, Australia, England, Canada, and the United States, as well as with the production of dozens of scholarly books and hundreds of publications.

\section{THE MARCH AND JUNE 2010 ISSUES}

Ecology and Society fills an interdisciplinary niche. Interest in publishing in the journal continues to increase. We continue to expand our qualified editorial board to meet the expansion, and accepted papers appear on the web as soon as they are ready for publication. Previously we collected all published papers into an issue twice a year. Starting this spring we have decided to publish four issues a year to provide a more comprehensive overview for the reader of the journal. However, as before, we will only write two editorials a year.

We are most pleased with the two current issues reported on here. They cover a broad spectrum of topics from long-term and even archaeological perspectives to traditional ecological knowledge, local practice, and diverse worldviews; comanagement, participatory assessments and experiments, to the social-ecological challenges of management biodiversity; valuing ecosystem services and performing ecosystem-based management, to stewardship of landscapes and seascapes and the role of social innovation and transformation, often in the context of vulnerability, adaptability, and resilience. Several papers deal with water issues, from collaborative learning platforms and participation, to transboundary water governance and institutional challenges. However, all of the published papers share the same nature of truly integrating the social and the ecological. 
All in all, there are close to 50 contributions with about half as part of the special features. Four of the special features are now ready and done. The first is Navigating Trade-Offs: Working for Conservation and Development Outcomes, edited by Bruce Campbell, Jeff Sayer and Brian Walker. This issue synthesizes lessons from integrated conservationdevelopment initiatives in developing countries. The contributions emphasize that at the heart of achieving positive outcomes are a core of institutional issues involving landscape governance, trust building, empowerment, and good communication, all implying long-term commitment by, and flexibility of, external actors. The second is Realizi ng Water Transitions: The Role of Policy Entrepreneurs in Water Policy Change, edited by Dave Huitema and Sander Meijerink, which explores how individuals instigate, implement, and occasionally prevent changes to water management policy. A third feature, edited by Daniel Bottom, Kim Jones, and Charles Simenstad, is titled Pathwa ys to Resilient Salmon Ecosystems and includes a series of articles that reflect on the past, present, and future of salmon fisheries management and their effect on the complex ecological and social systems of which they are a part. Lastly, the feature Managi ng Surprises in Complex Systems: Multidisciplinary Perspectives on Resilience, edited by Lance Gunderson and Pat Longstaff, presents ideas about resilience from a multidisciplinary vantage point. Thanks a lot to all of the guest editors for their tremendous work!

We receive many requests for special features, decline a lot, and invite those that we believe really can take an issue forward. In this context there are publications in the two issues that open four new special features: (1) Transitions, Resilience and Governance: Linking Technological, Ecological and Political Systems, (2) Resilience and Vulnerab ility of Arid and Semi-Arid Social Ecological Systems, (3) Long-term Vulnerability and Transfo rmation, and (4) Landscape Scenarios and Multifu nctionality - Making Land Use Assessment Operational.

Although Ecology and Society has become a globally recognized outlet for scholarship, it will inevitably be subject to change. Given Schumpeter's model, it may in the future be replaced by something totally new.
Responses to this article can be read online at: http://www.ecologyandsociety.org/vol15/iss2/art29/ responses/ 